\title{
PERCEPÇÃO DA CAMINHABILIDADE NO ENTORNO DA INTERSEÇÃO DAS AVENIDAS ENGENHEIRO CAETANO ÁLVARES E IMIRIM
}

WALKABILITY PERCEPTION IN THE SURROUNDINGS OF THE INTERSECTION OF AVENUES ENGENHEIRO CAETANO ÁLVARES AND IMIRIM

\section{taícia Helena Negrin Marques}

Arquiteta e Urbanista formada pela PUC - Campinas, Msc Arquitetura da Paisagem e Planejamento pela Universidade de Wageningen - Holanda, Doutoranda pela FAU-USP, Departamento

Paisagem e Ambiente. E-mail: marques.taicia@gmail.com

\section{TATiana Sancevero Batistela}

Arquiteta e Urbanista e Especialista em Análise Ambiental formada pela UEL, Mestre em Paisagem, Ambiente e Sustentabilidade pela FAU - UnB. E-mail: tsancevero.b@gmail.com

\section{RESUMO}

Dentre as discussões sobre como projetar cidades no século XXI, o desafio de reincorporar a dimensão humana em sinergia com a conservação ambiental é crucial quando objetivamos a melhora na qualidade de vida dos centros urbanos.

Em acordo a esta abordagem, esse estudo busca analisar a caminhabilidade no trecho ao redor da interseção das avenidas Engenheiro Caetano Álvares e Imirim, na zona norte de São Paulo, através da percepção do pedestre, qualidade urbana e ambiental, já que a região apresenta potencial estruturador para o desenvolvimento de um sistema de infraestrutura verde integrado ao núcleo ecológico da Cantareira.

Palavras-chave: Percepção do Pedestre; Caminhabilidade; Infraestrutura Verde; Urbanismo Sustentável

\section{ABSTRACT}

Among the discussions on how to design cities in the 21st Century, the challenge to reincorporate the human dimension in synergy with environmental conservation is crucial when the aim is to improve the life quality in urban centers. 
In accordance with this approach, this study seeks to analyze the walkability in the section around the intersection of the Avenues Engenheiro Caetano Alvares and Imirim, in the northern region of São Paulo, considering the perception of the pedestrian, urban and environmental qualities, as the region present structural potential for the development of a green infrastructure system integrated to ecological green core of Cantareira Mountains.

Keywords: Pedestrian Perception; Walkability; Green Infrastructure; Sustainable Urbanism.

\section{INTRODUÇÃO}

O desenvolvimento urbano de São Paulo principalmente a partir da década de 50, com base no movimento modernista, se pautou em planos que priorizaram a utilização dos automóveis como principal meio de transporte. As infraestruturas para acomodar um número cada vez maior de veículos foi responsável pela canalização e tamponamento de rios e córregos, pela supressão de áreas verdes e pela minimização dos espaços destinados aos pedestres.

A melhora na qualidade de vida urbana e consequente conservação ambiental sustentam a discussão aqui apresentada onde a dinâmica que envolve o pedestre e sua interação com o ambiente construído e natural é objeto maior de análise nessa pesquisa.

Ao proceder uma intervenção na paisagem urbana, entendemos que a ênfase deve se dar na inter-relação entre o homem e os elementos biofísicos. Para Benedict e McMahon (2006), a infraestrutura verde como estratégia de conexão entre homem e natureza pode revelar, identificar e proteger espaços de conexão, redes para conservação da terra e outros espaços abertos, ao lançar mão dos instrumentos de conservação, restauração e manutenção de um sistema de funções naturais, também pode prover distintos espaços de sociabilidade, de lazer e de benefícios econômicos para as pessoas.

Segundo Jan Gehl (2015), durante muito tempo o conhecimento sobre como as estruturas físicas influenciam o comportamento humano era baixo. Após anos de pesquisas e observações, acumulou-se razoável conhecimento sobre a questão e atualmente se percebe o quanto cuidar das pessoas na cidade é fato essencial para obtenção de cidades mais vivas, mais seguras, sustentáveis e saudáveis; todos objetivos de crucial importância no século XXI. 
Caminhar é o início, o ponto de partida. A vida em toda a sua diversidade se desdobra diante de nós quando estamos a pé. Em uma perspectiva mais ampla, uma infinidade de valiosas oportunidades sociais e recreativas podem aparecer quando se reforça a vida a pé. Em essência, caminhar é uma forma especial de comunhão entre pessoas que compartilham o espaço público como uma plataforma e estrutura. (GEHL, 2015) Quanto à percepção dos pedestres, quando falamos sobre, abordamos os sentidos humanos. O natural ponto de partida do trabalho de projetar cidades para pessoas é a mobilidade e os sentidos humanos, já que estes fornecem a base biológica das atividades, do comportamento e da comunicação no espaço urbano.

Nessa mesma linha de pensamento, Douglas Farr (2008), propõe estratégias para o que chama de bairros caminháveis, através de uma rede integrada de ruas capaz de possibilitar que pedestres, ciclistas e motoristas se movam de forma confortável pelo bairro e entre os bairros.

A fim de avaliar as condições de caminhabilidade a partir dos conceitos acima apresentados, foi selecionado o trecho de interseção entre as avenidas Imirim e Engenheiro Caetano Álvares, na zona norte de São Paulo. As condições atuais das vias e calçadas foram analisadas e interpretadas a partir de três aspectos principais: qualidade urbana, qualidade ambiental e percepção do pedestre.

\section{A DIMENSÃO HUMANA: O PEDESTRE}

Durante séculos, acreditou-se que cidades eram construídas para pessoas, ao qual se desenvolviam principalmente com base em séculos de experiência. Contudo, a partir da década de 50, a forma como as cidade foram planejadas e como se desenvolveram mudou drasticamente. Em sintonia com a florescente expansão urbana, teorias e ideologias começaram a substituir a tradição em projetar cidades por uma nova abordagem pautada pelo desenvolvimento, processo este fortemente influenciado pelo modernismo - uma das ideologias dominantes de planejamento. Neste novo contexto, a dimensão humana foi negligenciada acarretando baixa prioridade ao espaço público, às áreas de pedestres e ao papel do espaço urbano como local de encontro. (GEHL, 2015)

Em decorrência às consequentes mudanças no tecido urbano, devido a abordagem modernista, a jornalista e escritora americana Jane Jacobs (Morte e Vida das Grandes Cidades, 1961) foi a primeira voz forte a clamar por uma mudança decisiva na manei- 
ra como construímos as cidades. As cidades não eram mais construídas como conglomerações de espaço público e edifícios, mas como construções individuais. Segundo ela, corroborava à crise, o florescente tráfego de automóveis que estava espremendo o restante da vida urbana para fora da cidade. (JACOBS, 2000)

A introdução do carro e do tráfego de veículos foi decisiva também para o surgimento da confusão entre escalas e dimensões nas cidades. Os carros ocupam muito espaço quando se deslocam e muito espaço quando estacionados. Quando a velocidade nas áreas urbanas aumenta de 5 para 60 ou $100 \mathrm{~km} / \mathrm{h}$, toda dimensão espacial aumenta dramaticamente e as imagens e visões da paisagem urbana também se transformam. O senso de proporção e de escala , ao longo de 50 anos, foi sendo cada vez mais moldado pelo carro. Raramente é demostrada a capacidade de trabalhar objetivamente com as relações entre a escala humana e a escala do carro como duas disciplinas distintas, já que o problema do carro confundiu muito o entendimento da escala.

Para Gehl (2015), a dimensão humana é a perspectiva necessária de um novo planejamento, um maior foco sobre as necessidades das pessoas que utilizam as cidades reflete uma exigência distinta e forte por melhor qualidade de vida urbana. A visão de cidades vivas, seguras, sustentáveis e saudáveis tornou-se um desejo universal e urgente, demandando uma política urbana integrada. Os quatro objetivos-chave - cidades com vitalidade, segurança, sustentabilidade e saúde - podem ser imensamente reforçados pelo aumento da preocupação com pedestres, ciclistas e com a vida na cidade em geral.

Reforça-se a potencialidade para a cidade tornar-se viva e segura, sempre que mais pessoas sintam-se convidadas a caminhar e pedalar ou permanecer nos espaços públicos. Uma cidade que convida as pessoas a caminhar, por definição, deve ter uma estrutura razoavelmente coesa que permita curtas distâncias a pé, espaços públicos atrativos e uma variedade de funções urbanas.

A cidade sustentável é geralmente fortalecida se grande parte de seu sistema de transporte puder se dar por meio do deslocamento a pé, de bicicleta ou por transporte público. Um bom espaço esistema de transporte públicos são dois lados de uma mesma moeda. Quanto a questão de uma cidade saudável, este desejo é intensificado se o caminhar ou o pedalar forem etapas naturais do padrão de atividades diárias.

Quando abordamos a caminhabilidade compreendemos que um claro convite deve ser enviado à circulação de pedestres, implica que estes se sintam convidados a ca- 
minhar e a permanecerem em espaços públicos. Para tal deve-se iniciar um processo de melhores e mais seguras condições para o tráfego e permanência, este refletirá em novos padrões de uso da cidade. Entendemos que o fato de as pessoas serem atraídas para caminhar e permanecer no espaço público é muito mais uma questão de se trabalhar cuidadosamente com a dimensão humana e lançar um convite tentador.

Os elementos básicos do desenho urbano são espaços de movimento e espaços de experiência. A rua reflete o padrão de movimento linear dos pés e a praça representa a área que o olhar pode abarcar. No contexto do planejamento urbano, onde a relação entre sentidos, comunicação e dimensões é um tema importante, fala-se do campo social da visão. O limite desse campo é de 100 metros, quando podemos ver as pessoas em movimento. Outro limiar importante é o de 25 metros, quando podemos começar a decodificar emoções e expressões faciais. Essas duas distâncias são a chave de muitas situações físicas em que o objetivo é observar pessoas.

Outro aspecto importante norteador para o projeto e desenho urbano é o fato de que o homem evoluiu para mover-se lentamente e a pé. A orientação do corpo humano é linear, frontal, horizontal e caminha a velocidade normalmente máxima de $5 \mathrm{~km} / \mathrm{h}$. Nossos sentidos também se desenvolveram de modo a permitir movimentos lentos em superfícies principalmente horizontais. Caminhos, ruas e bulevares são todos espaços para movimentação linear, projetados com base no sistema humano de locomoção.

Em sinergia e complementarmente ao perfeito conhecimento da escala humana para estimular o tráfego de pedestres, estratégias de projeto que conectam o homem e a natureza se apresentam como potenciais na superação dos desafios apresentados nesse século, somando aspectos ecossistemicos à qualidade de vida urbana.

\section{INFRAESTRUTURA VERDE: UMA ESTRATÉGIA DE ALCANCE LOCAL}

A infraestrutura verde (IEV) se apresenta como nova estratégia de projeto para o meio urbano. Dado o tamanho e a diversidade ambiental, social e econômica de nossas cidades, grandes planos abrangentes já não são mais capazes de atender a toda demanda ambiental e social. Esta cuida de cada ambiente com atenção às suas condições biofísicas e sociais e mantêm foco nas redes regionais de espaços livres (RIBEIRO, 2010). O objetivo de tal estratégia é buscar o equilíbrio entre o ambiente natural e antrópico, adotando ações de conservação próprias do lugar para promover o desenvolvimento sustentável. 
Apesar de ser um conceito atual, a infraestrutura verde tem suas raízes em propostas que romperam paradigmas da disciplina de arquitetura da paisagem, através de visões multidisciplinares. A partir da primeira utilização do termo, nos anos 90 , este conceito vem recebendo várias definições, desde aquelas que relacionam o benefício "verde" do plantio de árvores até aquelas que associam essa estratégia ao desenho de infraestruturas de engenharia para a drenagem das águas de uma forma ecológica (BENEDICT, M. A. e MCMAHON, E. T, 2006). Para Benedict e McMahon (2001, p.05), infraestrutura verde:

(...) é definida como uma rede interconectada de espaços verdes que conserva os valores e funções dos ecossistemas naturais associados aos benefícios para os seres humanos. (...) Infraestrutura Verde se difere de abordagens convencionais para o planejamento de espaços abertos porque ela olha para valores e ações em conjunto com o desenvolvimento da terra, o gerenciamento do crescimento e a construção de um plano de infraestrutura (...)

Dessa forma, a infraestrutura verde é abordada como uma estratégia para o desenvolvimento urbano sustentável e resiliente. A rede verde multifuncional, resultante da implementação dessas estratégias, relaciona meio urbano e não urbanizado e pode ser implementada desde a escala do edifício ou lote até escalas regionais através de elementos conectores, pólos ou nós e fragmentos (BENEDICT, M. A. e MCMAHON, E. T, 2006), reconstituindo um mosaico de áreas verdes que impactam o uso e ocupação do solo ao longo do tempo (AHERN, 2007).

A qualidade de um projeto depende do equilíbrio que a intervenção estabelece entre a comunidade e os elementos previamente existentes. Há princípios ou parâmetros que podem e devem nortear as intervenções, atuando como marcos de referência a partir dos quais, dentro de um quadro de individualidade e singularidades, será capaz de responder às necessidades do lugar. A estratégia de ação que se denomina infraestrutura verde auxilia as comunidades a identificar e a priorizar as oportunidades dentro de um plano de desenvolvimento e de caminhos que otimizam um uso da terra que concilia as necessidades das pessoas e da natureza.

Essa estratégia aborda a natureza na cidade não apenas como um conjunto ou maIha de fragmentos e reservas naturais interconectados, mas também as estruturas próprias da urbanização, como ruas, calcadas, galerias de esgoto pluvial, jardins privados, entre outros. Parte da premissa de que cidades são lugares onde as pessoas trabalham, circulam, compram, satisfazem necessidades e, nesse cotidiano, devem conviver, reconhecer, apreciar e se identificar com os processos naturais. 
As ruas assumem nas cidades um caráter que lhes é peculiar, sem paralelo com outros espaços públicos. Ela talvez seja, no cotidiano, o espaço mais comunitário que temos e que apresenta grande potencial para implantação de IEV. Mas, devido ao seu caráter eminente de circulação, em nossa cultura, a rua é vista diretamente relacionada ao fluxo de veículos.

Como afirmou Jacobs (2000) nos anos 60, a tendência de usar ruas como espaços sociais é espontânea e natural. Elas são usadas por diferentes pessoas e distintas atividades. Na sua diversidade de usos e atividades, elas vão definindo sua vocação social, o que extrapola seu desenho de apenas unir lugares, de ser elo de ligação. Não é sem razão que os woonerf, empregados nas cidades holandesas, fizeram e fazem tanto sucesso, pois eles reconhecem e fomentam a multifuncionalidade da rua, a diversidade das atividades sociais, reafirmando esse espaço como lugar de convívio e troca de experiências, do qual o carro não esta excluído, mas não é visto como elemento que dita as regras à urbanização (RIBEIRO, 2010).

Entendemos que nem todas as ruas podem assumir esse papel de lugar de encontro e permanência para atividades de lazer e contemplação, mas a grande maioria pode ter o enfoque que não simplesmente de ligação. Podem ser projetadas e constituírem elos verdes que ligam ambientes e funções, impondo-se como lugares agradáveis e saudáveis no meio urbano.

Quando adentramos à análise de ruas caminháveis, Douglas Farr (2008) apresenta a perspectiva de rede integrada. Uma rede integrada de ruas possibilita que pedestres, ciclistas e motoristas se movam de forma confortável pelo bairro. Quando se desenha uma rua deveríamos garantir primeiro sua qualidade para o pedestre e depois para acomodar carros, caminhões e veículos de segurança.

Farr (2008) indica uma transição do desenho de ruas projetadas para acolher os automóveis para ruas que tem um caráter multimodal, "planejamento de contexto- sensível" (context-sensitive planning - CSS) e são desenhadas de forma multidisciplinar. CSS aponta para uma série de objetivos que incluem: suporte para bairros orientados ao desenvolvimento compacto; caminhabilidade nos bairros e uso misto do solo; sistema de transporte multimodal (passagem, bicicleta, caminhada, automóvel); aumento da compatibilidade com os usos do solo adjacentes; provisão de espaços públicos de alta qualidade estética e para atividades; aumento da qualidade de vida; proteção da qualidade meio ambiental. 
Nesse contexto, análises urbanísticas, meio ambientais e que demonstrem a percepção dos próprios usuários ao espaço percorrido através da caminhada, se tornam ferramentas complementares para o desenvolvimento de ações eficazes de melhorias do espaço urbano e garantia de percursos seguros, confortáveis, interessantes e funcionais para os pedestres.

\section{RECORTE TERRITORIAL: A INTERSEÇÃO DAS AVENIDAS ENGENHEIRO CAETANO ÁLVARES E IMIRIM}

Muitas vias de transporte, em especial para mobilidade de maior velocidade, foram responsáveis pela canalização de rios e córregos, redução das áreas verdes e, com a conversão do uso do automóvel privado como principal meio de transporte, perda dos espaços destinados ao pedestre e ao convívio. Como recorte para o estudo, foi escolhida a avenida Engenheiro Caetano Álvares, um exemplo dessa relação predadora entre infraestrutura e ambiente e um potencial eixo a ser requalificado, como catalizador do desenvolvimento urbano e ambiental associado à melhora do espaço pedonal na região norte de São Paulo. Sua posição topográfica, nas planícies aluviais do córrego do Mandaqui, recebe as águas de toda a bacia hidrográfica referente a este curso d'água extrapolando os limites territoriais delineados pelos divisores dos bairros da região (Limão, Casa Verde, Santana e Mandaqui), conforme indicado nas Figuras 01 e 02.

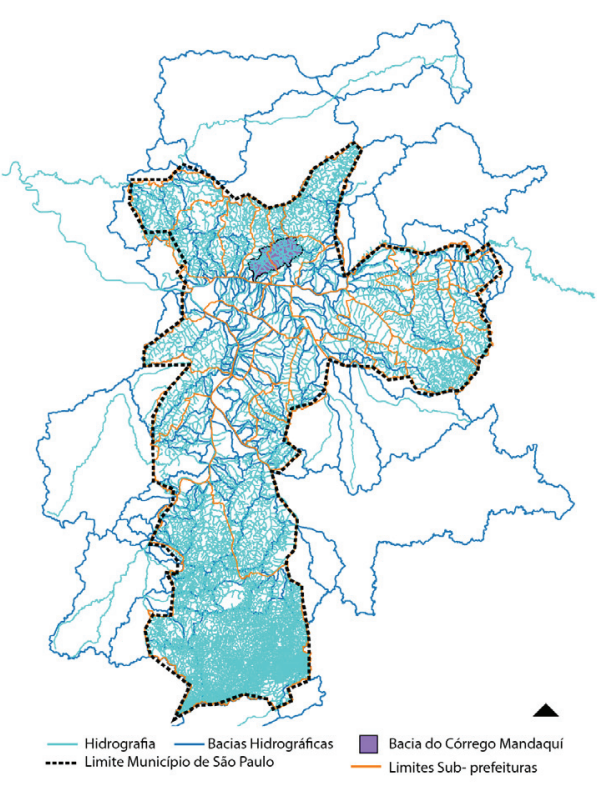

Figura 01 - Localização da Bacia do córrego Mandaqui no contexto de São Paulo.

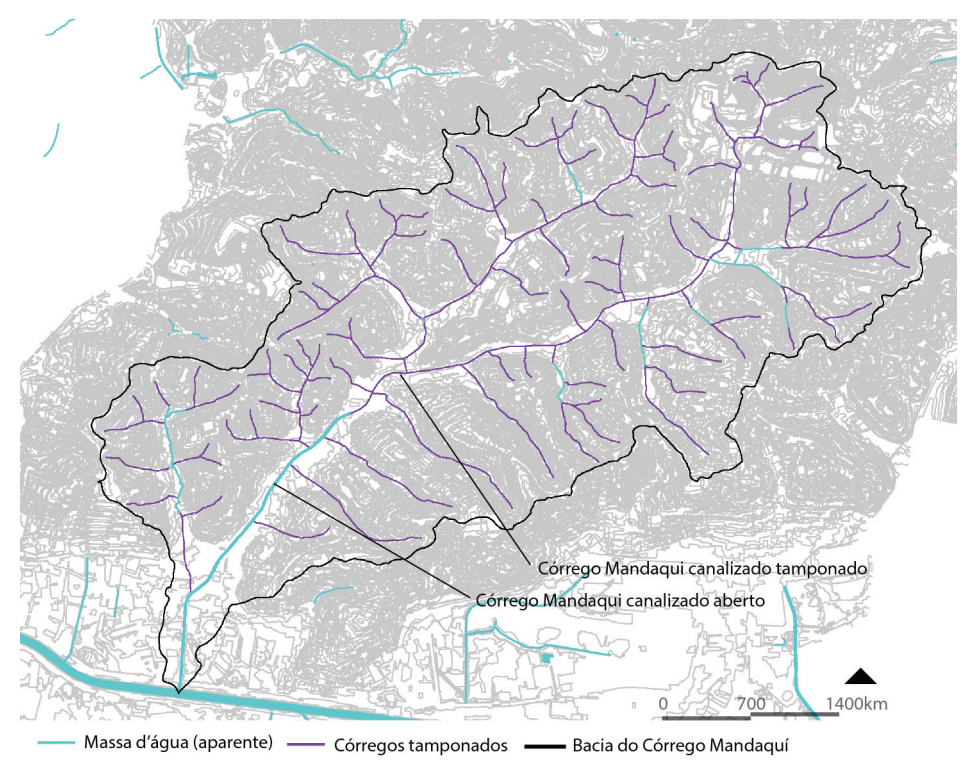

Figura 02 - Bacia do córrego Mandaqui com Hipsometria e indicação de áreas de córrego aberno ou tamponados. Fonte: elaborado pelas autoras 
Ao ser consolidado, nos anos 70, como um importante eixo de mobilidade que conecta as áreas mais próximas à avenida marginal do rio Tietê àquelas lindeiras ao Parque Estadual da Cantareira, a avenida contribuiu para o rompimento do já fragilizado elo de ligação ecossistêmica entre a matriz vegetal encontrada na Cantareira e as áreas da várzea do Tietê, impulsionando consigo a ocupação extensa das áreas adjacentes que levaram à canalização da grande maioria dos córregos que formam a bacia do Mandaqui. A construção da avenida retirou o próprio córrego da paisagem urbana, tamponando este curso d'água em mais da metade de seu trajeto e ao deixá-lo a céu aberto, o enclausurou entre profundas paredes de concreto. A localização dos trechos abertos ou tamponados pode ser vista na Figura 02.

Entender o quão amigável ao pedestre é esta área, partindo do princípio exposto por Farr (2008), que uma via deve ser primeiramente planejada visando o pedestre, nos levou a reconhecer inicialmente os pontos de maior importância quanto à geração de fluxo pedonal ao longo da avenida Engenheiro Caetano Álvares. Seguindo este objetivo, foi feita a análise do uso de solo prevalecente ao longo do eixo, o que resultou na identificação do uso predominante por comércios e serviços.

Uma característica que chamou atenção foi a grande frequência de usos com foco no usuário de automóveis privados, representados por inúmeras lojas de compra e venda de carros e oficinas mecânicas que dominam a paisagem na via, com maior ou menor intensidade, mas constantemente presentes, desde o cruzamento com a avenida Casa Verde, próxima à Marginal Tietê, até a interseção da Rua Voluntários da Pátria, próxima à região da Cantareira (Figuras 03 e 04). Esses comércios são eventualmente interrompidos por restaurantes e casas noturnas, além de um hipermercado e alguns bancos. Por seu uso do solo dominado por essas tipologias, sem muita variedade e atratividade ao pedestre e sem contar com o uso misto residencial, foi verificado um fluxo maior de pedestres em vias transversais à avenida Eng. Caetano Álvares ou no seu canteiro central arborizado, do que nas calçadas da via. 

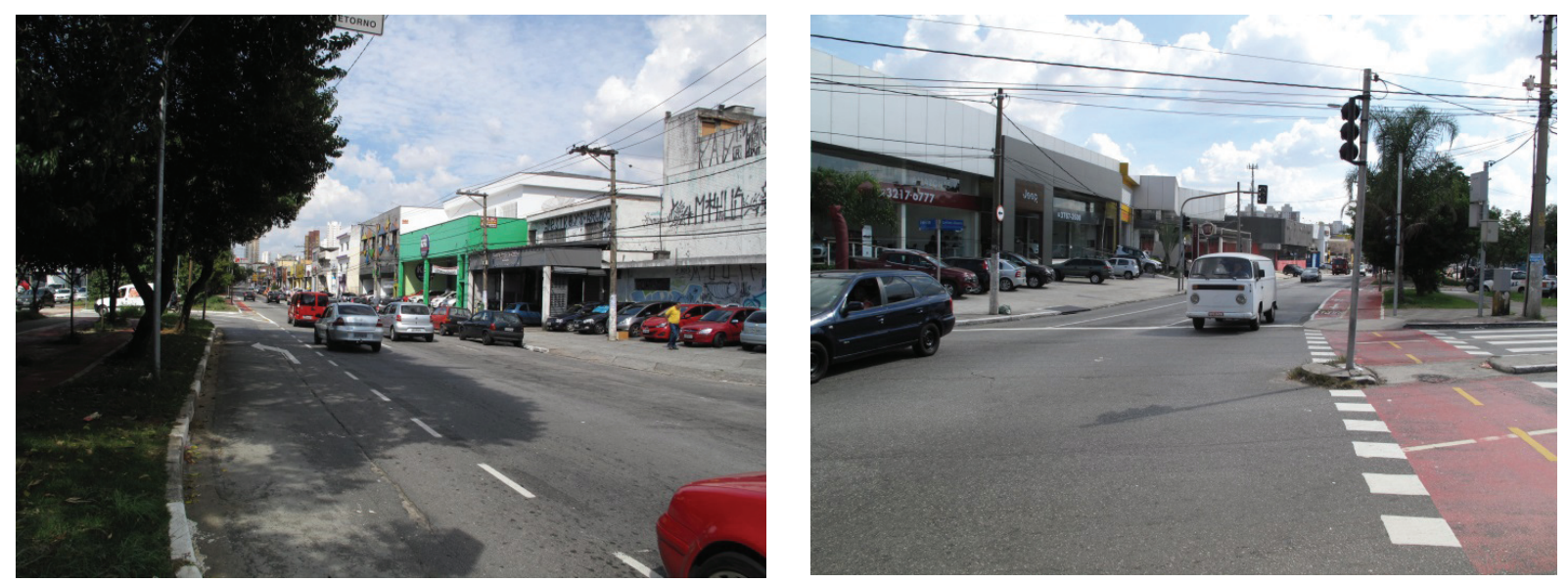

Figuras 03 e 04 - Uso comercial predominante de lojas de venda e conserto de carros.

Fonte Figuras: T.H.N. Marques (2016)

Cinco cruzamentos de maior movimento não apenas de pedestres, mas também de ônibus e automóveis privados se destacam: Rua Voluntários da Pátria; Rua ConseIheiro Moreira de Barros; Av. Imirim; Rua Zilda; conjunto das avenidas Casa Verde e Mandaqui (Figura 05). Todos os eixos contam com áreas de uso predominantemente de comércio e serviços, porém diferem no tipo de comércio e serviço, o que impacta na escolha do pedestre quanto a seu destino.

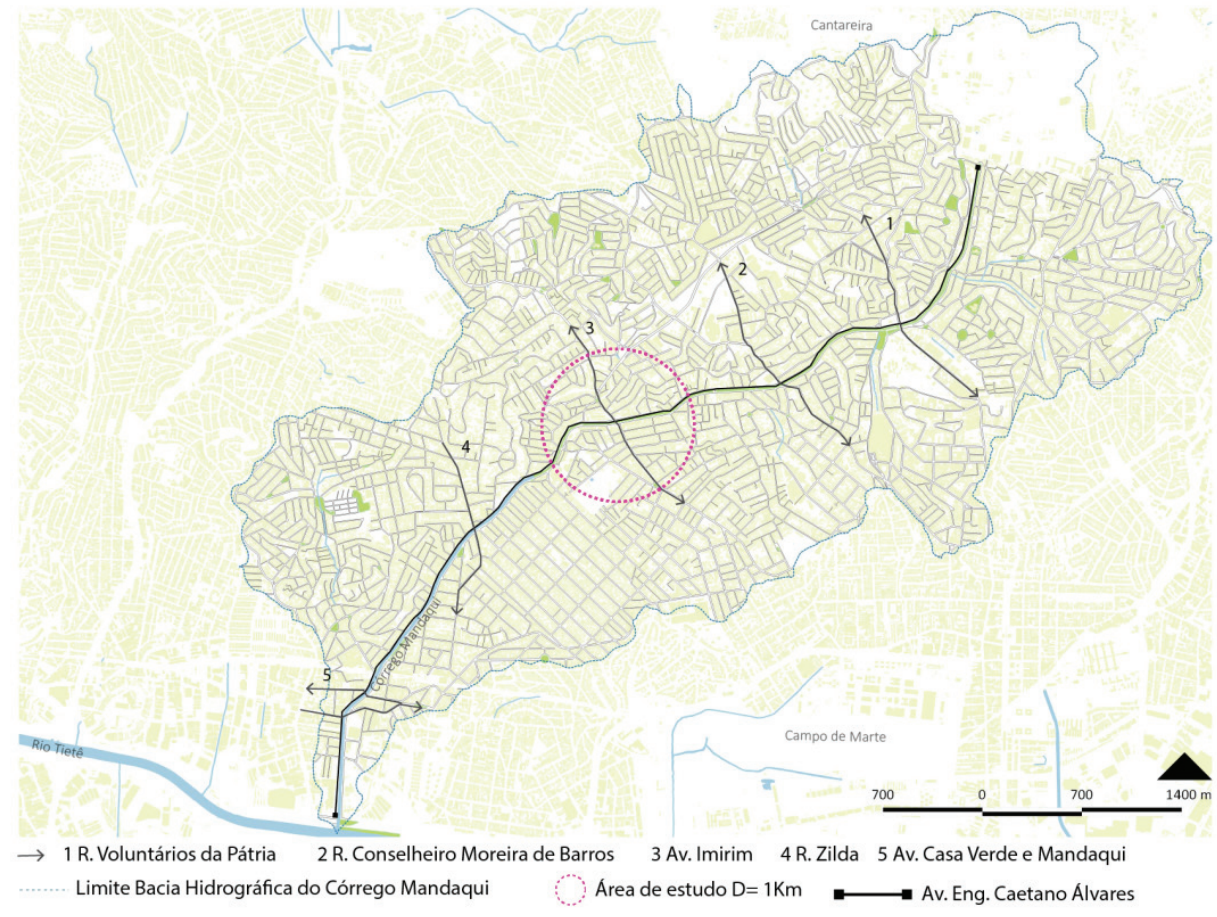

Figura 05 - Implantação geral da av. Engenheiro Caetanos Álvares na várzea do córrego Madaqui e cruzamentos de maior fluxo. Fonte: elaborado pelas autoras 
Para este estudo de caso, foi selecionado o entrocamento da avenida Imirim com a Eng. Caetano Álvares, como local demonstrador de fluxos de pedestres. Para uma amostragem das possíveis diferenças que ocorrem ao longo dessa avenida e sua relação com o eixo principal da Caetano Álvares, foi utilizado um diâmetro aproximado de $1 \mathrm{~km}$ de extensão a partir da interseção das duas avenidas. Essa distância é considerada propícia para que uma pessoa caminhe com tranquilidade (Farr, 2008; Gehl, 2015) atendendo a demandas de bairros caminháveis.

\section{METODOLOGIA}

A partir da definição do recorte de estudo, utilizou-se métodos mistos, quantitativos e qualitativos focados em compreender as características ambientais, espaciais e funcionais além do aporte da percepção dos pedestres, os quais foram agrupados durante a análise emqualidade urbana, qualidade ambiental e percepção do pedestre. A soma dessas variáveis possibilitou uma visão multidimensional mais rica do ambiente caminhável (KEPPEL, 1991 apud CRESWELL, 2009, p. 159).

Os métodos quantitativos englobaram análises e interpretação de dados a partir de processos de geoprocessamento e os processos qualitativos englobaram análises de documentos e imagens de satélite, visitas de observação in-loco e aplicação de questionário de perguntas fechadas. A soma dos métodos forneceu a interpretação dos critérios ambientais, espaciais, funcionais e de percepção pedonal.

Para a coleta de dados a respeito da qualidade das vias e calçadas (qualidade urbana) e da percepção dos pedestres foi utilizada a matriz " Índice de Qualidade Ambiental Percebida" (Perceived Environmental Quality Index - PEQI) desenvolvida pelo Departamento de Saúde Pública de São Francisco, Califórnia, EUA, e aprimorada pela Universidade da Califórnia (UCLA, PEQI v3,2016), para aplicação em Los Angeles. Esta ferramenta foi traduzida e teve as medidas de distância e velocidade, inicialmente dispostas em pés e milhas por segundo respectivamente, adaptadas ao padrão brasileiro de metros e quilômetros por hora. O índice é dividido em dois formulários de questões fechadas e respostas escaladas, um para a avaliação das condições das interseções e outro para a avaliação dos segmentos de ruas. $\mathrm{O}$ "Formulário de Interseção" possui apenas itens relacionados à qualidade espacial do entroncamento de vias. O "Formulário de Segmentos" é dividido em cinco partes, sendo as quatro primeiras focadas na qualidade espacial segundo blocos de itens 
quanto ao tráfego de veículos, às calçadas, ao uso do solo e à segurança e qualidade estética. A última das cinco partes avalia a "Percepção de Caminhabilidade" do pedestre de forma mais subjetiva.

O PEQI foi elaborado de tal forma a ser utilizado pelos próprios moradores de determinado bairro para a avaliação das condições de caminhabilidade a partir de suas percepções. No presente estudo, os itens considerados qualitativos físicos foram preenchidos pelas pesquisadoras, enquanto aqueles que correspondem à percepção da qualidade do entorno, ou seja, qualidade visual do trecho, barulho, cheiro, sentimento de segurança e avaliação da caminhabilidade foram perguntados a um grupo de 30 pessoas abordados em um ponto específico do cruzamento das avenidas Imirim e Engenheiro Caetano Álvares, no dia 03 de maio de 2016 entre 9h e 12h. Além das questões do PEQI, foram adicionadas outras referentes à origem e destino dos entrevistados e comentários que pudessem ter a respeito da escolha do caminho percorrido.

Após a coleta de dados in-loco foi utilizada a planilha de análise, disponível no PEQI, para formatar as informações de tal forma que pudessem ser interpretadas e associadas aos dados gerados através de manipulações de mapas e imagens de satélite por geoprocessamento. Paralelamente, as entrevistas foram sistematizadas fornecendo através de gráficos a perspectiva do pedestre frente ás condições de caminhabilidade em três trechos: Av. Eng. Caetano Álvares, Av. Imirim trecho norte e Av. Imirim trecho Sul. Essa divisão foi feita seguindo as diferenças de qualidade urbana encontradas durante o estudo, sendo a primeira avenida homogênia, enquanto a av. Imirim apresentava diferenças representativas entre seus trechos.

\section{ANÁLISE}

A análise da qualidade urbana e ambiental foi elaborada dentro de todo o perímetro da área de estudo, incluindo a av. Direitos Humanos, que possui um importante caráter conector, quase paralelo ao eixo localizado na várzea do córrego Mandaqui, e que impacta diretamente o fluxo de veículos e de pedestres que utilizam o trecho da av. Imirim até a Engenheiro Caetano Álvares. Quanto à percepção do pedestre, as avenidas que compõem a interseção da área de estudo, Engenheiro Caetano Álvares e Imirim, foram priorizadas. Dessa forma, a seguir são apresentadas as análises referentes à: qualidade urbana, qualidade ambiental e percepção do pedestre. 


\section{Qualidade Urbana}

A qualidade urbana relacionada à caminhabilidade foi elaborada a partir da sobreposição das informações relacionadas ao uso de solo predominante, dispostas na Figura 06, e pelas quatro primeiras partes de análise das condições de caminhabilidade segundo o PEQI tanto para os segmentos quanto para as interseções de vias, conforme apresentado na Figura 07. A fim de compreender os principais motivos que levam as pessoas a caminhar pela área e a durabilidade dessa ação, foram incorporadas à qualidade urbana as questões quanto à origem/ destino e tempo de duração do percurso coletadas nas entrevistas.

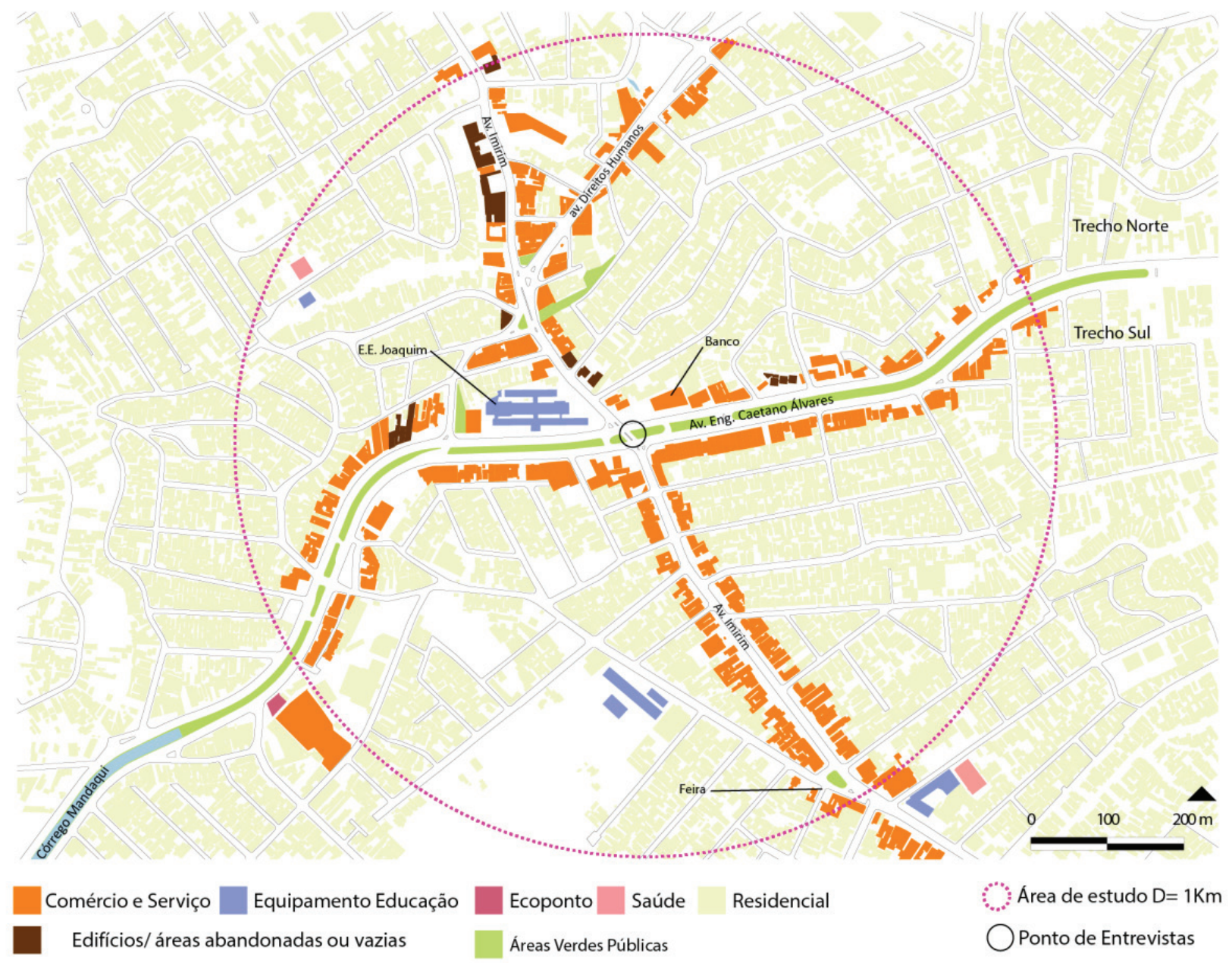

Figura 06 - uso do solo predominante no trecho de estudo. Fonte: elaborado pelas autoras 


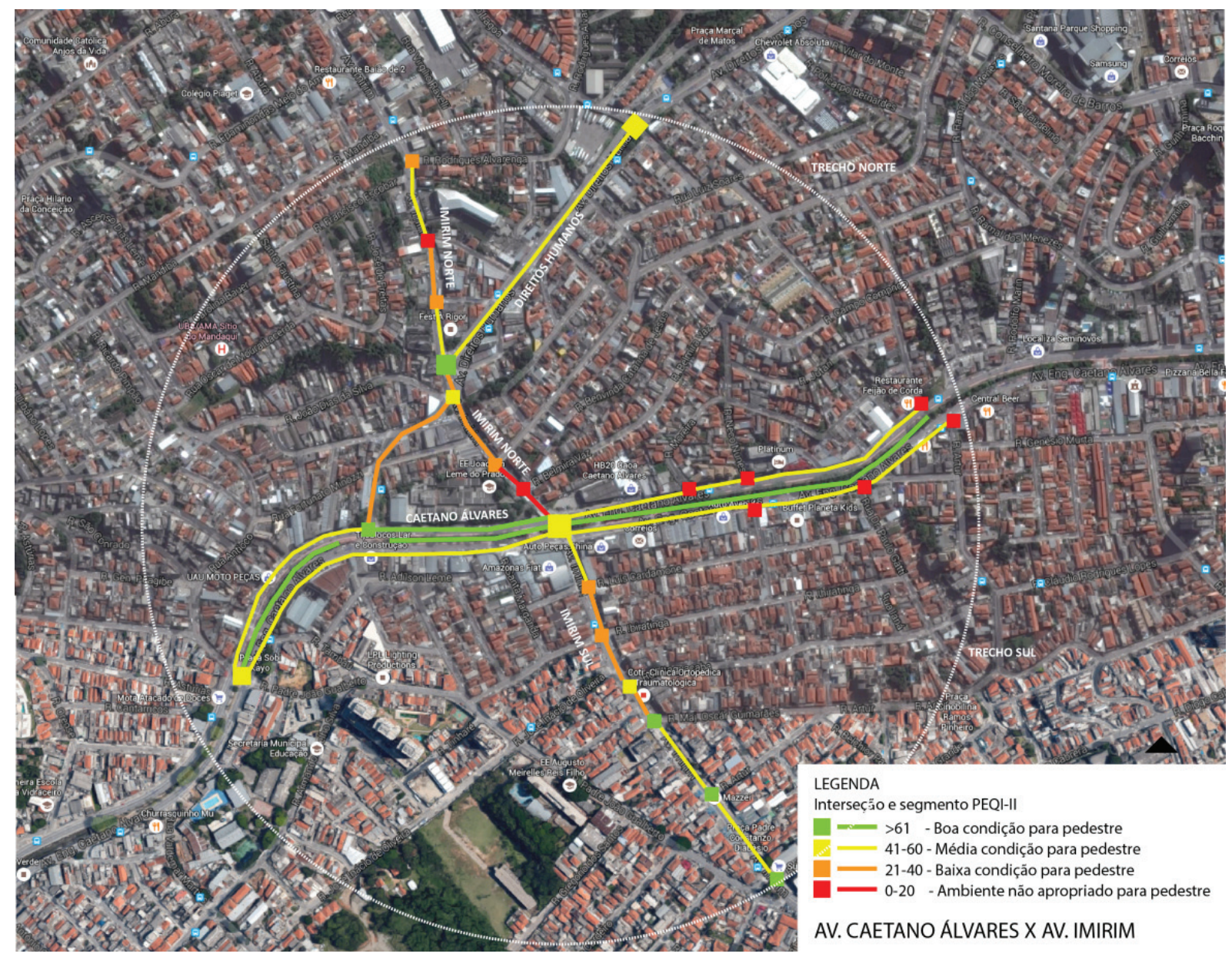

Figura 07 - resultado análise PEQI. Fonte: elaborado pelas autoras

A avenida Eng. Caetano Álvares foi investigada quanto às características de suas calçadas e também do seu canteiro central pelo PEQI. A avenida é ladeada por lojas de comércio de automóveis e oficinas mecânicas. Na interseção com a av. Imirm, trecho norte, ainda existem alguns equipamentos grandes, como a E.E. Joaquim Leme do Prado e uma agência bancária do Bradesco. Além disso possui algumas residências, porém em sua maioria fechadas à espera de serem vendidas e um centro comercial também vazio no momento. As calçadas ao longo da avenida são largas, com cerca de $3,00 \mathrm{~m}$, e o maior desconforto acaba sendo as inúmeras interrupções para acesso de veículos às lojas e serviços automobilísticos e a falta de arborização ou áreas verdes nessas calçadas. Além disso, por não ter um uso do solo diverso, as áreas de calçadas da av. Eng. Caetano Álvares não são muito atrativas para o pedestre. Paradoxalmente, é na área onde o córrego Mandaqui está tamponado, no canteiro central, que o verde ressurge como espaço apropriado pelos pedestres e utilizado com maior intensidade que as calçadas desse eixo de mobilidade. Nessa área, do canteiro central, estão associadas as ciclovias, uma faixa 
para pedestres e equipamentos de ginástica que favorecem o uso do espaço também como área de lazer e esporte (Figura 08 e 09). Outra área verde existente aí é uma praça localizada nos fundos da escola, ao lado da interseção da av. Direitos Humanos com a Eng. Caetano Álvares, a qual atualmente está ocupada por moradores de rua.

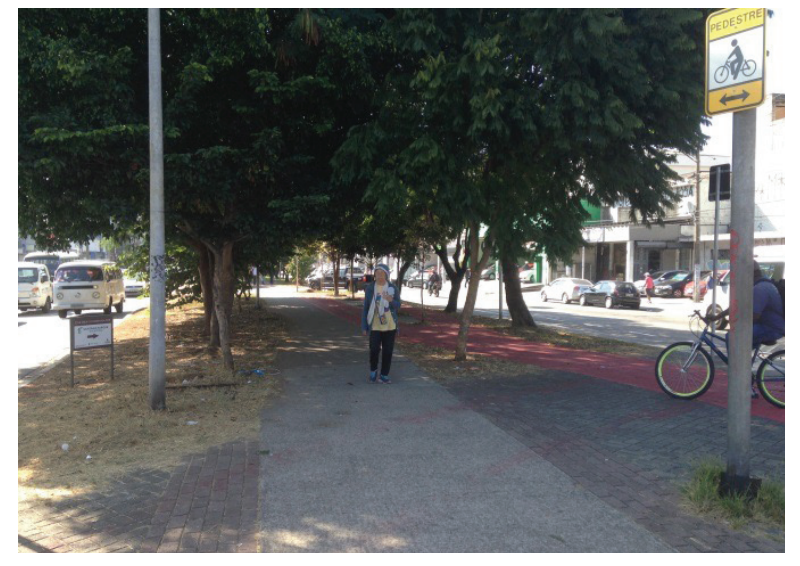

Figura 08 - Canteiro Central

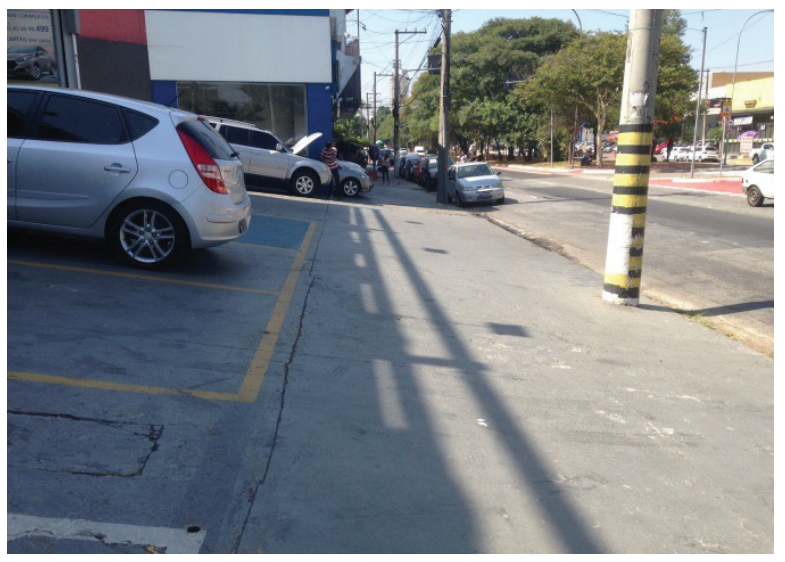

Figura 09 - Calçada lateral norte.

Fonte: T.H.N. Marques (2016)

$\mathrm{Na}$ interseção da av. Eng. Caetano Álvares com a av. Imirim apenas três sentidos de travessia a pé são permitidos, porém um quarto sentido acaba sendo utilizado pelos pedestres, que pela inexistência de infraestrutura correm risco de atropelamento (Figuras 10 e 11). No geral, mesmo tendo boa pontuação pelo PEQI as travessias dessa área seguem a prioridade do automóvel e não do pedestre, possuindo semáforos demorados e sem contadores, faixas de travessia localizadas em pontos que exigem maior caminhada, sem iluminação para o caminhante ou redutores de velocidade.
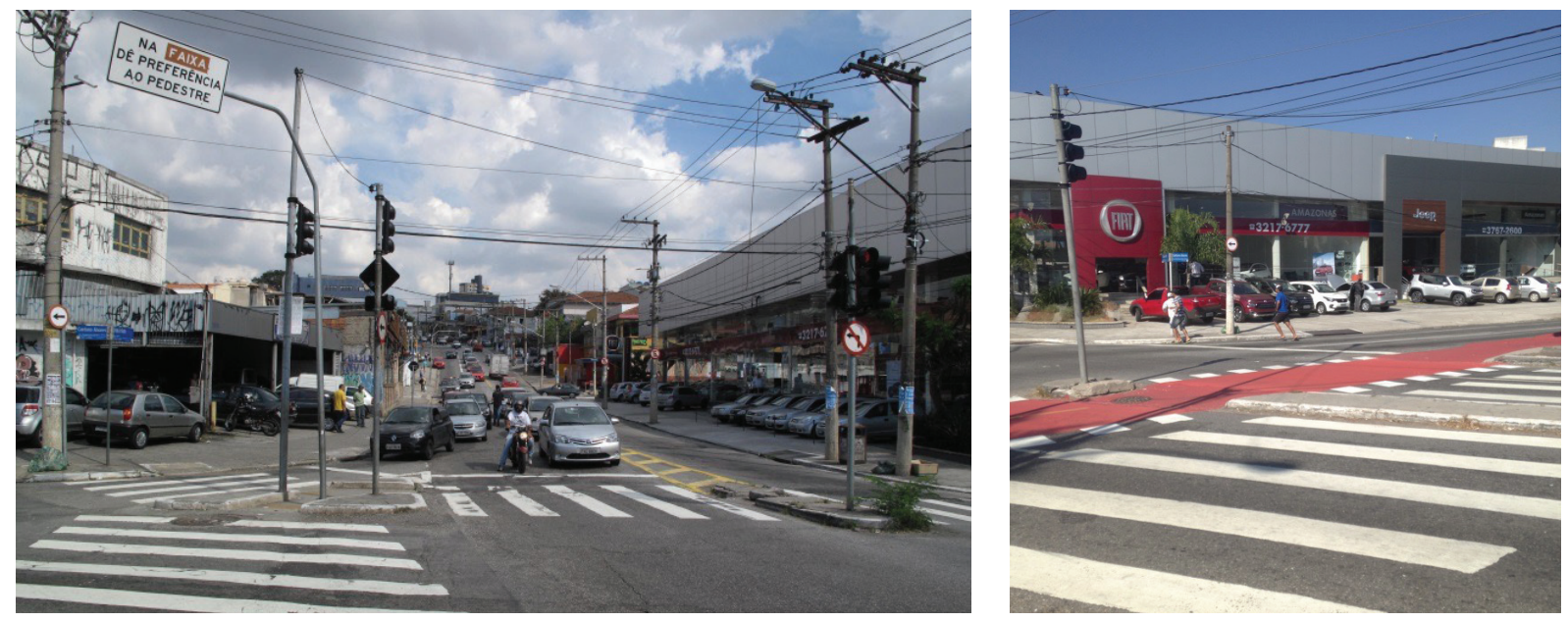

Figuras 10 e 11 - cruzamento av. Imirim (lado sul) x av. Engenheiro Caetano Álvares.

Fonte: T.H.N. Marques (2016) 
Enquanto a avenida Engenheiro Caetano Álvares apresenta homogeneidade quanto às suas características urbanas, a avenida Imirim difere bastante quanto à qualidade espacial e de uso do solo entre seus trechos norte e sul. Embora o fluxo de pedestres seja alto dos dois lados da avenida, as qualidades urbanas mudam bastante. No trecho norte, na área de interseção com a avenida Caetano Álvares, encontra-se a Escola Estadual Joaquim Leme do Prado, geradora de grande fluxo de estudantes em três horários pico, ao redor das $7 \mathrm{~h}$ da manhã, entre as 12:30 - 13h e ao redor das 18:30 h. Além disso, a presença de um banco na esquina em frente à escola é responsável por fluxos principalmente em torno das $12 \mathrm{~h}$ e a presença de pontos de ônibus dos dois lados da avenida Imirim garante um movimento constante de pedestres que utilizam o transporte público para percorrerem distâncias mais longas.

As calçadas em frente aos dois equipamentos, na interseção com a av. Eng. Caetano Álvares, sofre um alargamento significativo (Figura 12), o que, mesmo sem mobiliário urbano, oferece espaço para que os jovens ou outros moradores da áreas se encontrem casualmente ou se reunam antes ou depois das aulas. O restante das calçadas, ao longo da av. Imirim (norte), passam a ser muito estreitas, entre 1,20 e 2,00 m e sofrem a concorrência de elementos fixos ou temporários, como postes, muros, degraus e/ ou carros nas calçadas, que dificultam a circulação pedonal e trazem sentimento de insegurança (Figura 13). Além disso, os diversos acessos a garagens e estacionamentos comerciais torna a calçada irregular e mais perigosa para a caminhada. Outro elemento que influi no quesito segurança são os edifícios ou lotes abandonados encontrados ao longo de todo o trecho norte da via.

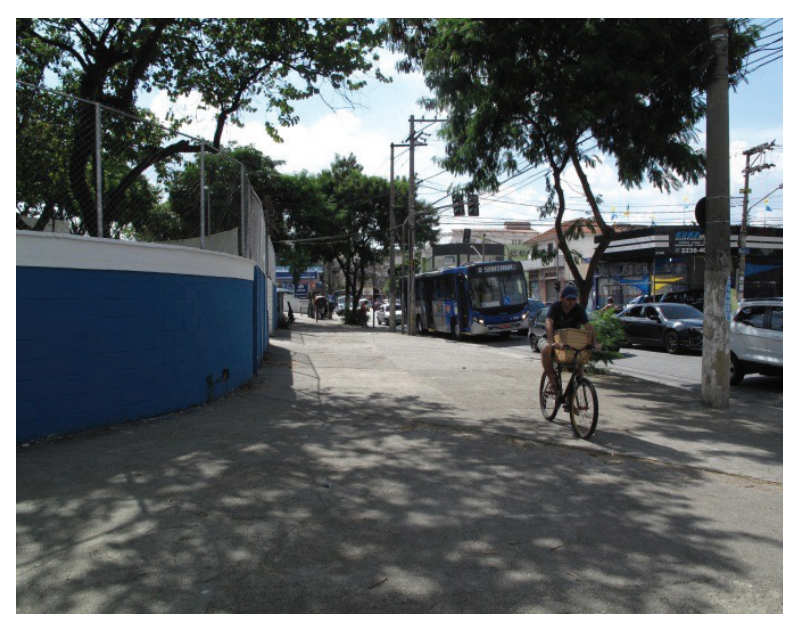

Figura 12 - alargamento na esquina da E.E. Joaquim Leme do Prado;

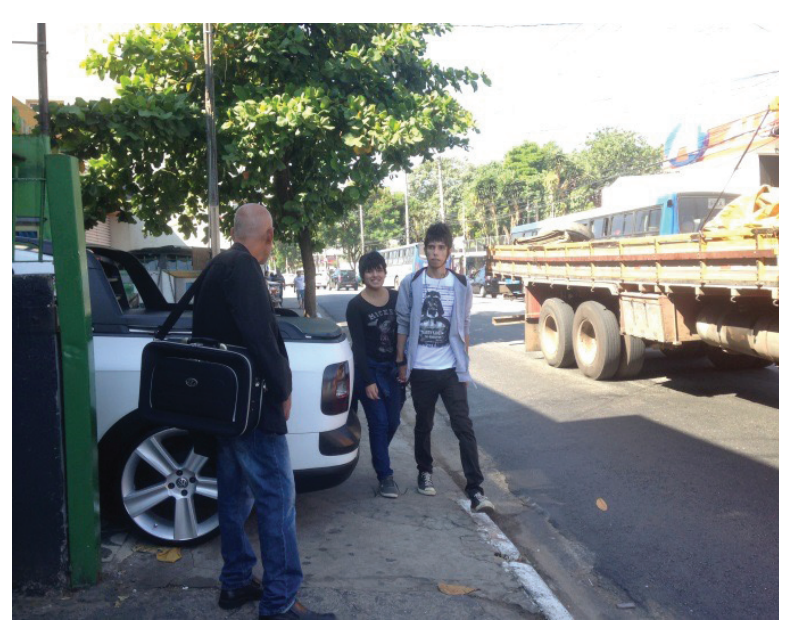

Figura 13 - exemplo calçada trecho Imirim Norte. Fonte: T.H.N. Marques (2016) 
Seguindo pela av. Imirim em direção norte, após o cruzamento com a av. Direitos Humanos, a primeira se torna mais inóspita, com calçadas ainda mais estreitas e o uso de solo predominante de oficinas mecânicas ou lotes abandonados.

O trecho sul da avenida Imirim segue desde a av. Eng. Caetano Álvares até a rua llha Grande. Na interseção com a av. Caetano Álvares, mantem o uso do solo homogênio encontrado aí com grande predominio de lojas e oficinas de carros, mas conforme segue em direção sul passa a ter um caráter de comércio diverso frequentado por pedestres, tais como lojas e pequenos mercados com calçadas mais largas e não muito escalonadas o que permite uma melhor caminhabilidade embora a via se torne ingrime nesse trecho. A presença de feira livre na altura da rua llha Grande, traz um caráter pedonal importante para a área e dinamiza as ruas próximas. Esta área possui um caráter de centralidade de bairro, onde é possível encontrar agencias bancárias, correios, pequenos mercados, escolas e igreja.

Quanto à avenida Direitos Humanos, esta via possui uma conformação mais larga que a av. Imirim, conta com ciclovia de mão dupla em uma de suas margens e calçadas que variam entre $1,20 \mathrm{~m}$ e 3,00 m aproximadamente. Essas características fazem com que no geral, a via tenha uma qualidade melhor para a caminhabilidade. No entanto, a presença de longos muros de estacionamento e ainda muitas oficinas mecânicas, faz com que o percurso seja percebido como perigoso e desinteressante.

Nas áreas interiores aos bairros, entre as avenidas, a ocupação é quase homogênia, formada por moradias de até três pavimentos. Os lotes dessas regiões normalmente são de dimensões pequenas, com testadas variando entre 5 a $10 \mathrm{~m}$ de largura e calçadas de aproximadamente 1,20 a $2 \mathrm{~m}$ de largura, enquanto as vias variam quanto à inclinação, sinuosidade e largura. Essa conformação fundiária, somada ao tipo de construção residencial resulta em calçadas muito fragmentadas pelos acessos às garagens e inclinadas em direção ao viário. Além disso, o fator relevo, acentuado em algumas áreas internas dos bairros, colabora para o escalonamento das áreas destinadas aos pedestres formando obstáculos para a circulação.

Embora as características físicas das áreas pedonais tenham sido identificadas pelo PEQI em melhores condições ao longo da av. Caetano Álvares, durante as entrevistas ficou claro o uso da av. Imirim mais constante para as atividades diárias, associadas principalmente à moradia, escola, agencia bancária, trabalho nos comércios dessa avenida e acesso aos pontos de ônibus como meio principal de transporte público 
para percorrer médias distâncias, como demonstrado nos gráficos 01 e 02.

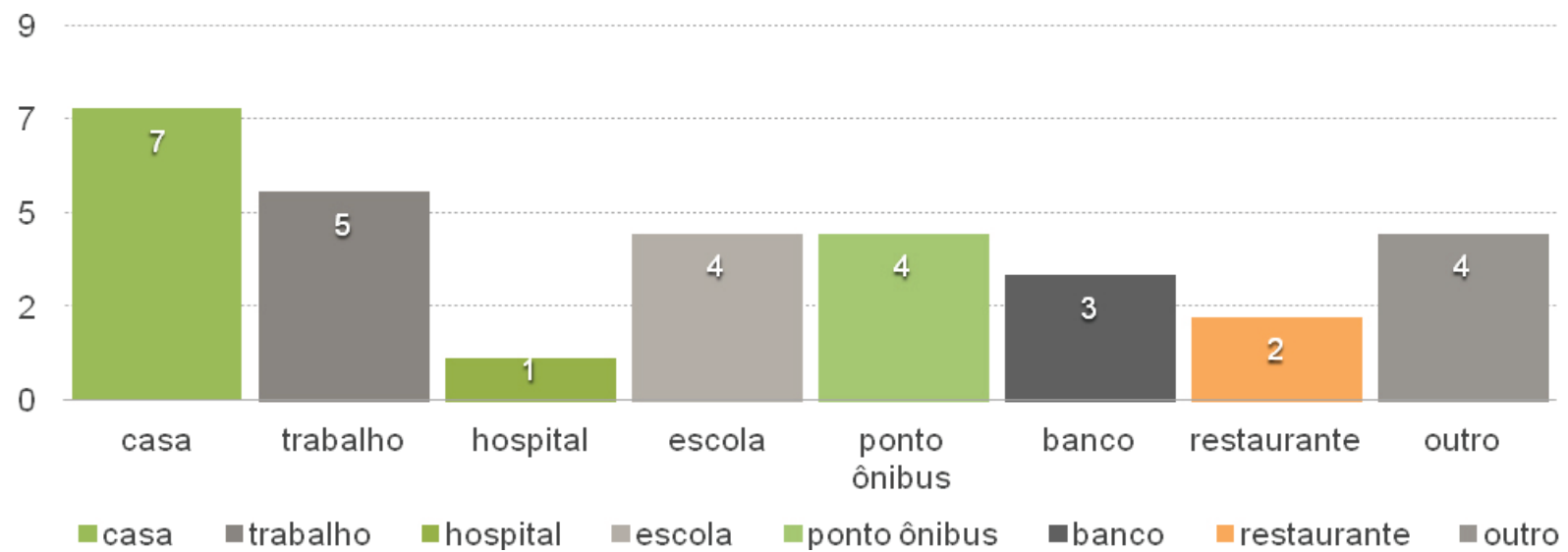

Gráfico 01 - origem (De onde você está vindo?)

15

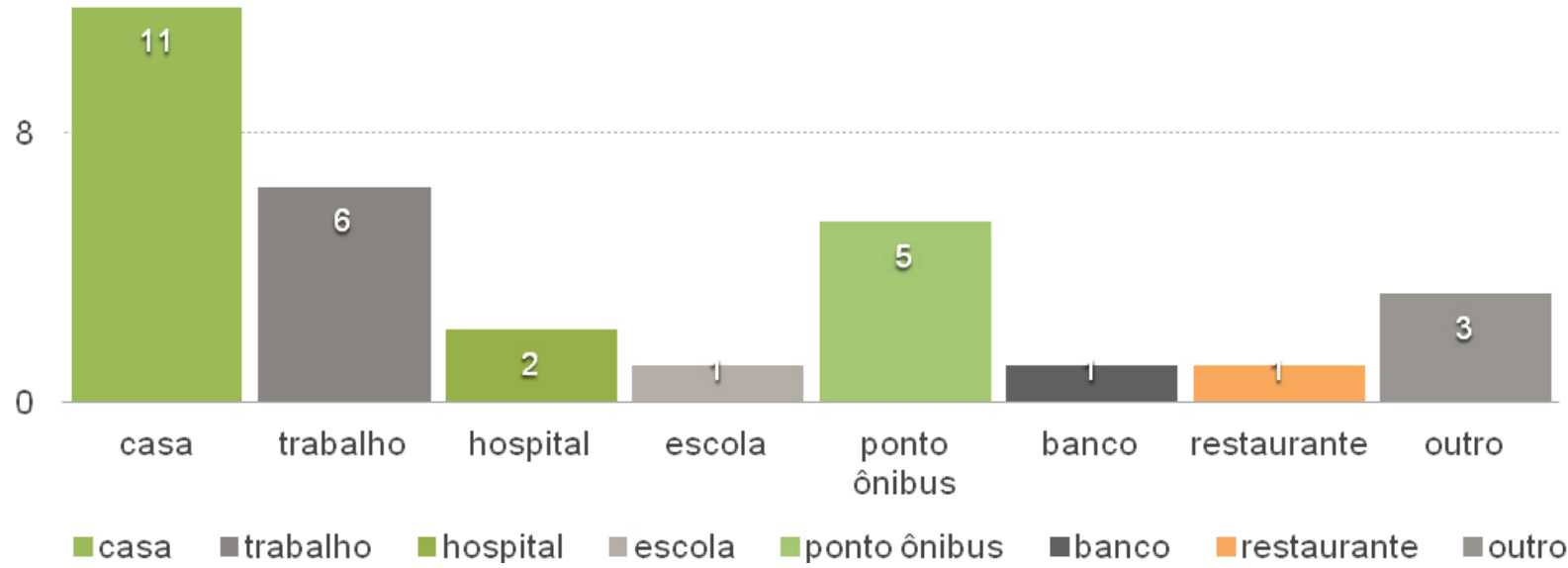

Gráfico 02 - destino (Para onde você está indo?)

No gráfico 03 é possível compreender a predominância de tempo aproximado de caminhada dos pedestres. Embora a média de até 20 minutos seja mais frequente é interessante notar o número de pessoas que caminhavam mais do que 30 minutos. Este dado está relacionado, sobretudo à presença de pessoas que fazem atividades físicas ao longo da avenida Engenheiro Caetano Álvares, indicada nos gráficos 01 e 02 , apresentados anteriormente, dentro da categoria "outro". 


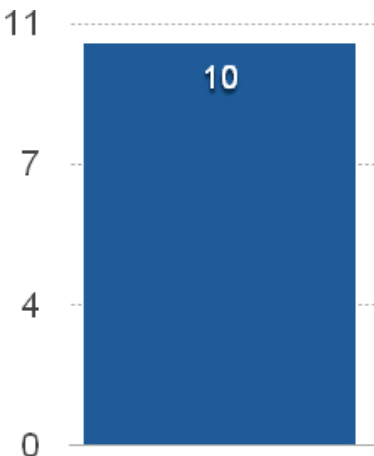

até $5 \mathrm{~min}$.

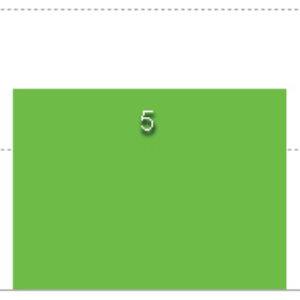

cerca $10 \mathrm{~min}$.

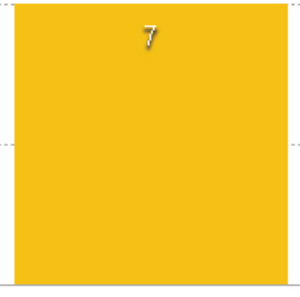

cerca $20 \mathrm{~min}$.

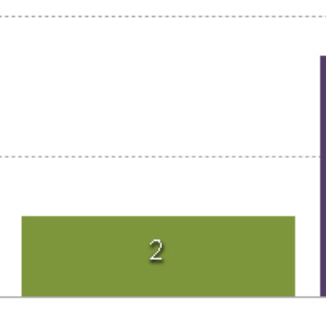

cerca $30 \mathrm{~min}$.

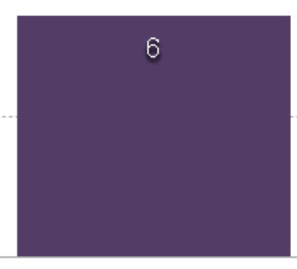

$>30 \mathrm{~min}$.

घaté $5 \mathrm{~min}$. घerca $10 \mathrm{~min}$. $\quad$ cerca $20 \mathrm{~min}$. $\quad$ cerca $30 \mathrm{~min} . \quad \square>30 \mathrm{~min}$.

Gráfico 03 - tempo médio de caminhada

\section{Qualidade Ambiental}

Para a análise das questões relacionadas à qualidade ambiental foram coletados dados que refletem a existencia de áreas verdes, as condições dos corpos d'água e de temperatura de superfície aparente. Quanto às áreas verdes, a média de metros quadrados por subprefeitura em 2011, é indicada como alta ou acima da média em Santana/Tucuruvi e Casa Verde/Cachoeirinha, cujos limites estão sobre a avenida Imirim (SVMA, 2011). Isso ocorre por conta da presença de parte do Parque Estadual da Cantareira e do Horto Florestal, ao norte dessas subprefeituras (Figura 14). Já a quantidade de áreas verdes existente ao longo do tecido urbano contradiz o dado anterior, pois no geral a vegetação é muito rarefeita, normalmente encontrada em pequenas praças ou associadas a equipamentos, como escolas e hospitais além de árvores pontuais ao longo das vias.

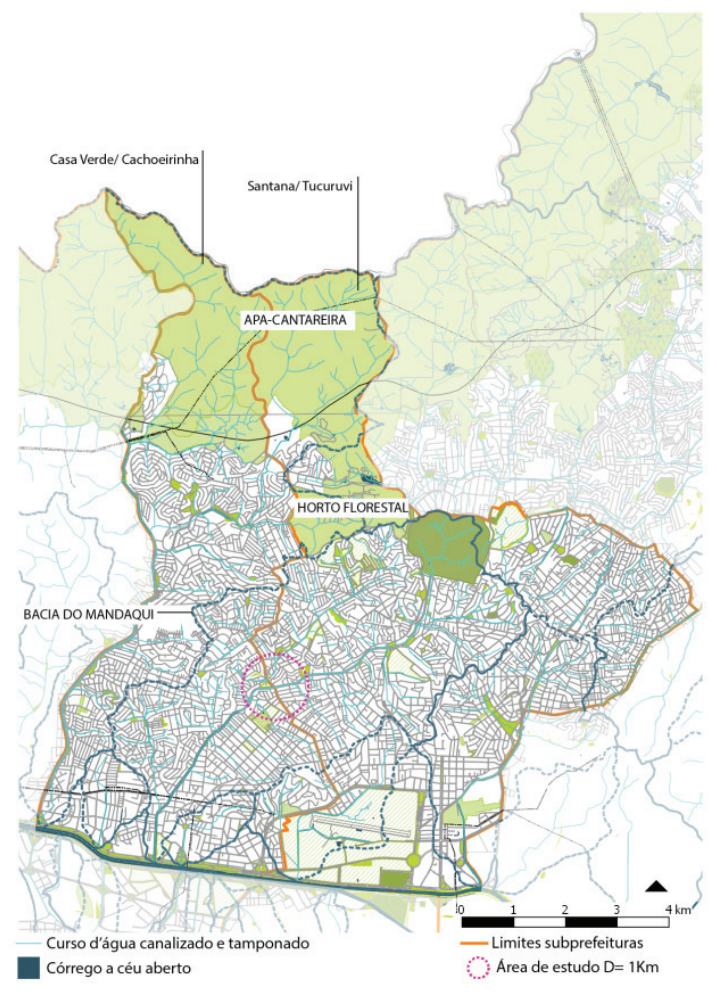

Figura 14 - subprefeituras, áreas verdes e azuis. Fonte: elaborado pelas autoras 
Analisando o recorte apontado como objeto desse estudo, com excessão do canteiro central da av. Eng. Caetano Álvares, uma praça no entroncamento desta com a av. Direitos Humanos e uma viela arborizada no trecho da avenida Imirim norte, a presença de áreas verdes se restringe a árvores pontuais ao longo das vias, à arborização junto às escolas e a pequenas praças. No interior dos bairros a arborização viária é ainda mais esporádica pela própria dimensão muito estreita das calçadas (Figura 15).

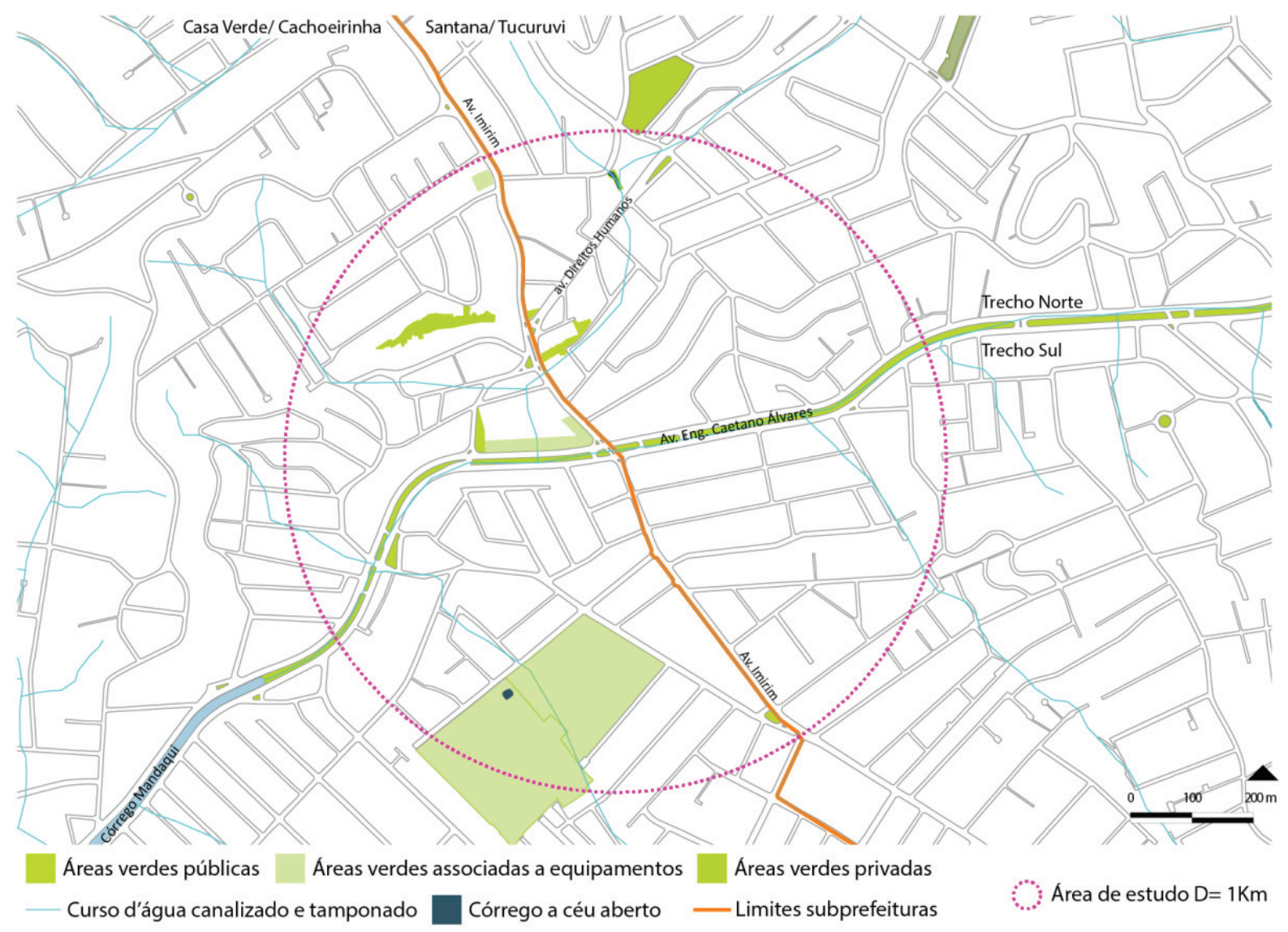

Figura 15 - recorte do estudo, áreas verdes e azuis. Fonte: elaborado pelas autoras

Quanto aos cursos d'água presentes na área de estudo, todos fazem parte da bacia do córrego Mandaqui e com a excessão de um pequeno riacho nas proximidades da av. Direitos Humanos, se encontram canalizados e enterrados em galerias (Figura 11). As águas dessa bacia hidrográfica foram consideradas limpas após o Programa Córrego Limpo, parceria da Sabesp e da Prefeitura municipal de São Paulo, ter sido implementado em 2015 (Folha de São Paulo, 2015). Porém, a poluição difusa ainda é um problema, assim como a necessidade de criação de estratégias que possam fazer com que a vida aquática retorne às águas dos córregos da bacia do Mandaqui. 
A falta de áreas verdes e azuis (rios e córregos), permeando o tecido urbano associada a fatores climáticos, físicos e antrópicos resulta em temperaturas mais altas urbanas na área de estudo. Segundo dados do Atlas Ambiental de São Paulo (2002) a área de interseção da av. Imirim com a Eng. Caetano Álvares é a que possui temperatura aparente de superfície mais alta quando comparada ao restante do eixo (Figura 16), chegando a temperaturas médias de cerca de 3 a $4^{\circ} \mathrm{C}$ mais altas em relação às áreas da Cantareira. Essa diferença térmica é percebida durante a caminhada e caracteriza a formação de uma Ilha de calor urbana (UHI).

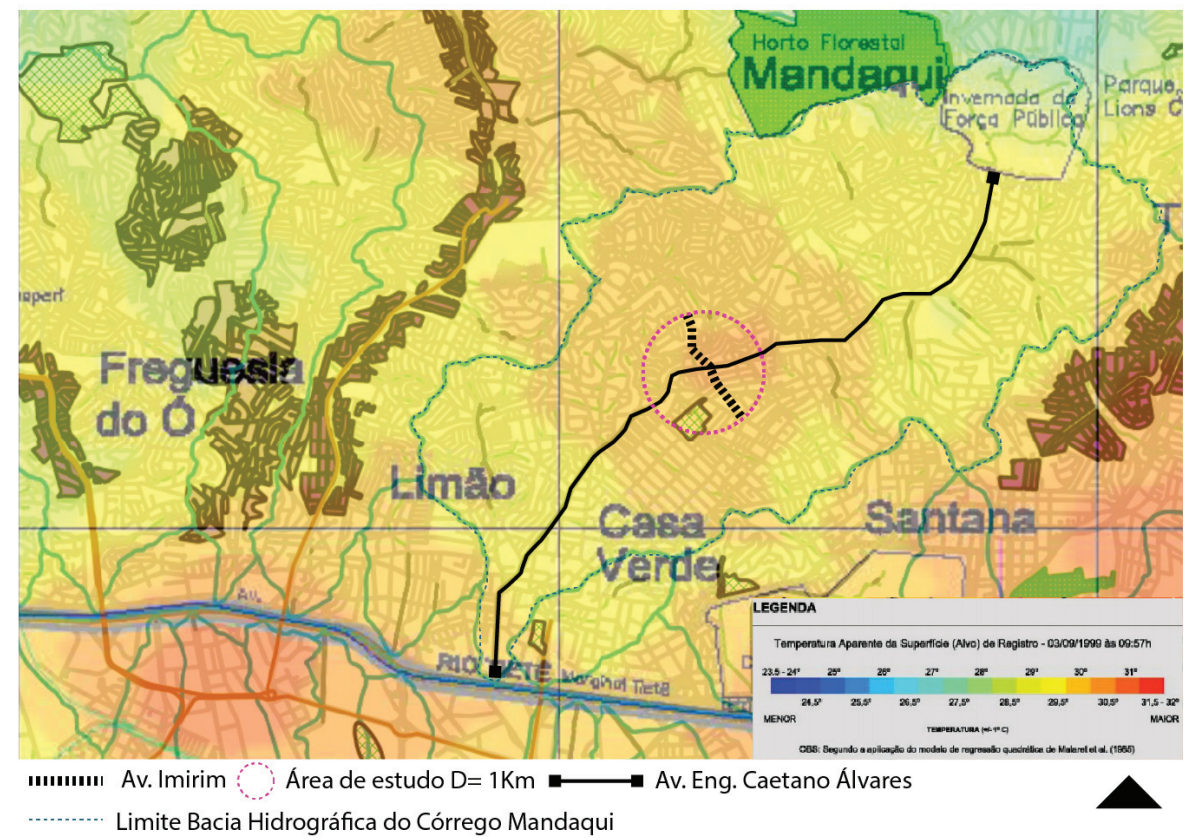

Figura 16 - Temperatura Aparente da Superfície na Bacia do córrego Mandaqui. Fonte: Atlas Ambiental. Mapa elaborado pelas autoras

\section{Pecepção do pedestre}

A coleta das percepções dos pedestres foi feita em um único ponto, no entroncamento das avenidas Engenheiro Caetano Álvares e Imirim. Os pedestres foram escolhidos de acordo com o local daonde estavam vindo, sendo: 10 do trecho norte da av. Imirm até av. Eng. Caetano Álvares, 10 estavam caminhando ao longo da avenida Eng. Caetano Álvares em ambas direções e 10 estavam vindo do trecho sul da av. Imirm até a avenida Eng. Caetano Álvares. No geral, a percepção dos pedestres foi condizente com as análises urbana e ambiental. Enquanto os pedestres vindos do trecho norte ou sul da avenida Imirim diferiram a respeito da percepção da caminhabilidade, aqueles caminhando pela avenida Eng. Caetano Álvares tiveram respostas muito similares independentemente da direção que vinham. Esse fato se relaciona diretamente com 
à constatação da homogeneidade de uso do solo ao longo da via no trecho estudado. Outro dado interessante foi a indicação, pelos pedestres, da preferência pelo caminho no canteiro central às calçadas da Caetano Álvares devido à prática de atividade física ou porque seu destino não estava localizado nos próximos 5 minutos de caminhada. Os pedestres consideravam este o local mais confortável devido às boas condições do pavimento e arborização. Essas considerações também foram associadas à atração visual pela via, conforme demonstrado no gráfico comparativo 04.

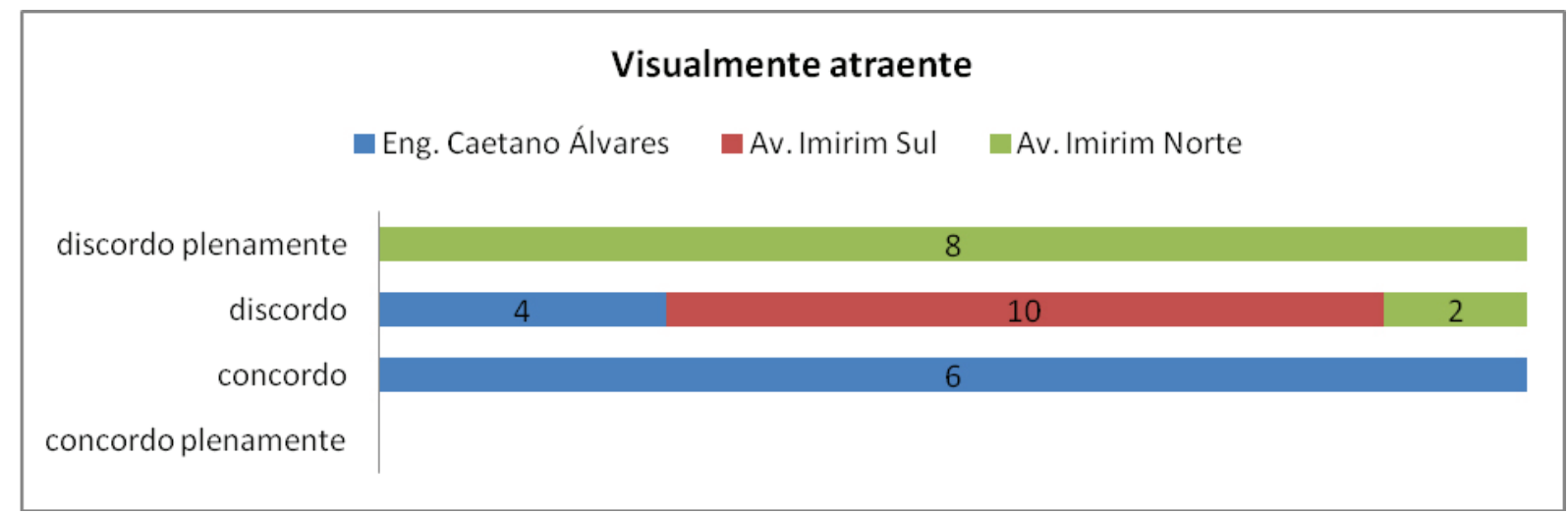

Gráfico 04 - Comparativo Percepção do pedestre quanto à qualidade visual da via

A avenida Engenheiro Caetano Álvares é considerada visualmente a mais atraente da área. Isso se deve sobretudo à presença de arborização ao longo do canteiro central e pela própria largura das vias e calçadas, que garantem ao mesmo tempo um enquadramento da paisagem e uma visão ampla a partir da perspectiva do pedestre. Já os trechos da avenida Imirim, mais áridos são considerados menos agradáveis visualmente, principalmente a sul onde as áreas verdes e arborização viária são raras.

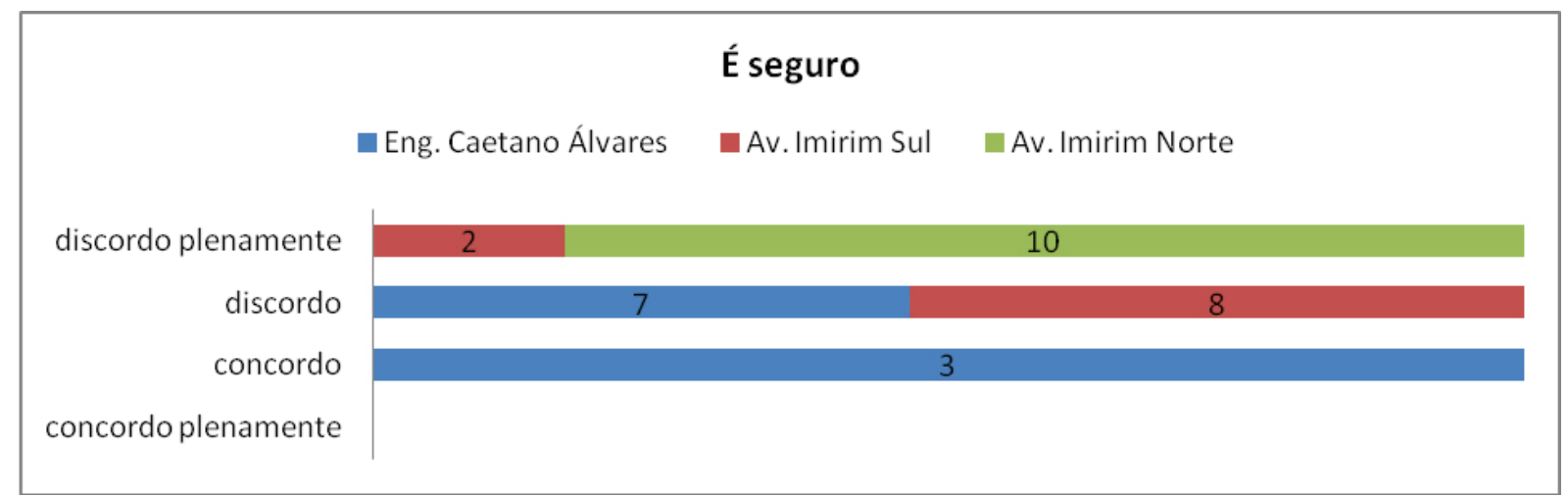

Gráfico 05 - Comparativo Percepção do pedestre quanto à segurança da via 
Quanto ao sentimento de segurança, conforme apresentado no gráfico 05, a av. Caetano Álvares também obteve melhores conceitos que a av. Imirim. Os pedestres que discordaram com a afirmação (7) associaram o sentimento à proximidade da ciclovia que compartilha o espaço do canteiro central. Os imóveis vazios e calçadas muito estreitas foram os principais fatores apontados pelos pedestres do trecho norte da av. Imirim como motivos para insegurança. No trecho sul essa sensação ainda era alta, mas pelo movimento mais constante de pedestres e calçadas mais largas foi considerado ligeiramente mais seguro que o primeiro trecho da avenida Imirim.

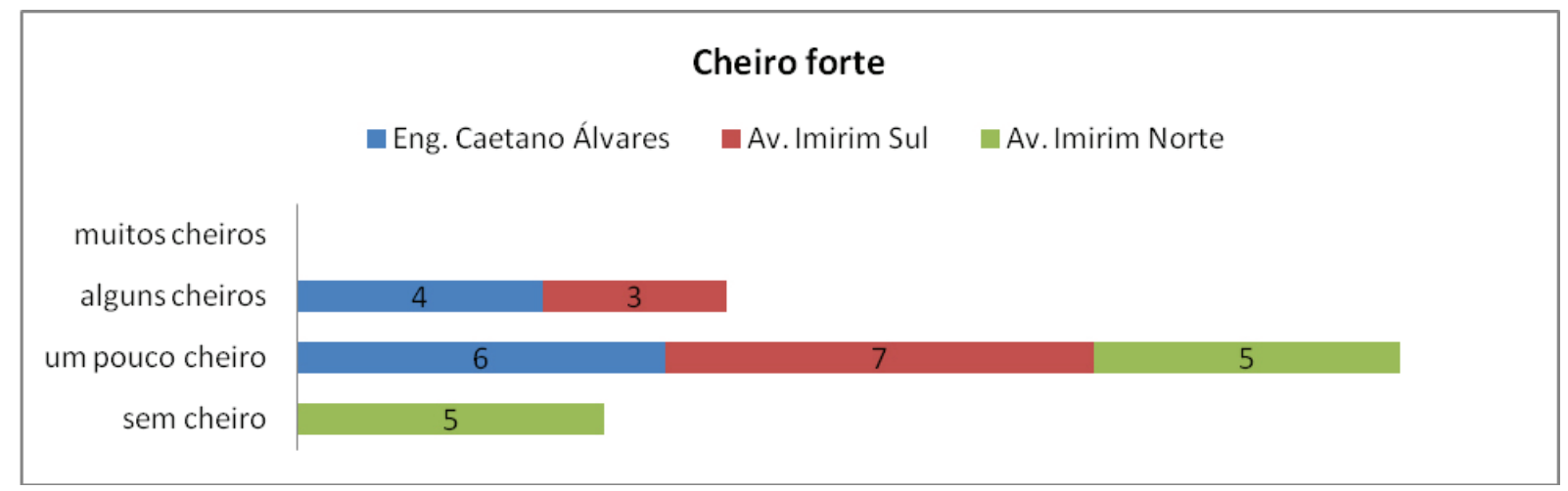

Gráfico 06: Comparativo Percepção do pedestre quanto à presença de cheiro forte

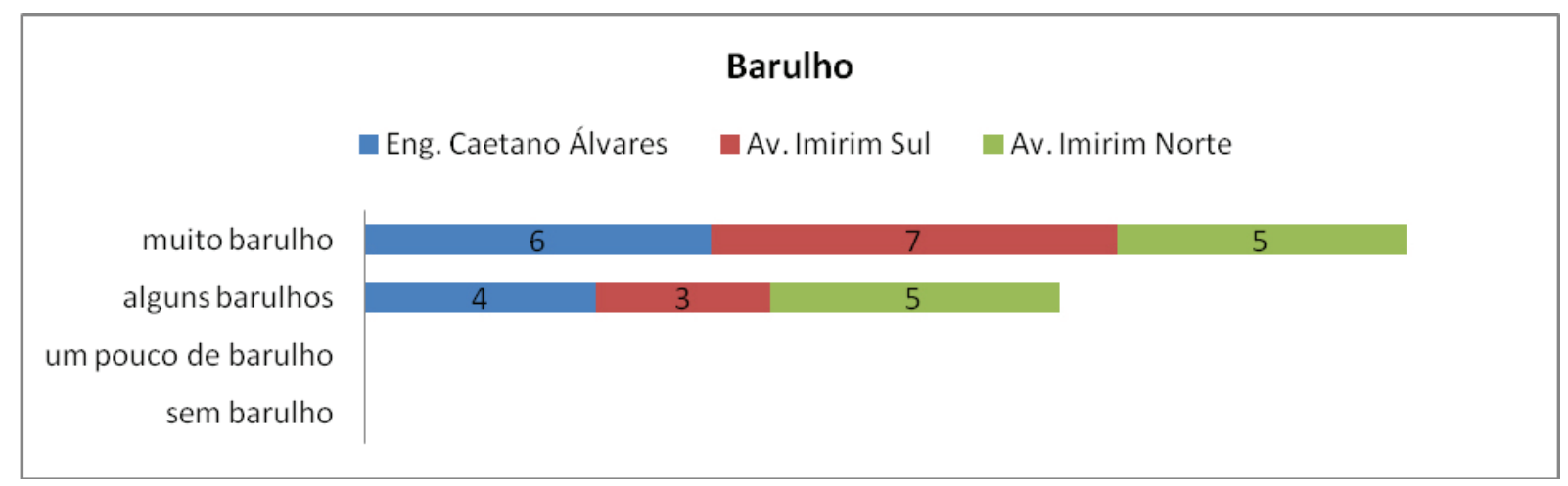

Gráfico 07 - Comparativo Percepção do pedestre quanto ao barulho

Conforme sintetizado no gárfico comparativo 06, em relação ao cheiro, os trechos com pior avaliação foram a av. Eng. Caetano Álvares e o trecho sul da av. Imirim. No geral, o principal incômodo percebido foi da própria poluição emitida pelos ônibus e demais veículos nos três trechos, além disso, no trecho sul da Imirm, a própria feira livre, foi considerada como área de mal cheiro. Assim como o odor, o barulho (Gráfico 07), foi em geral atribuído aos veículos que trafegam nas via, sendo percebido de forma intensa em todos os trechos, principalmente na parte sul do trecho Imirim. 


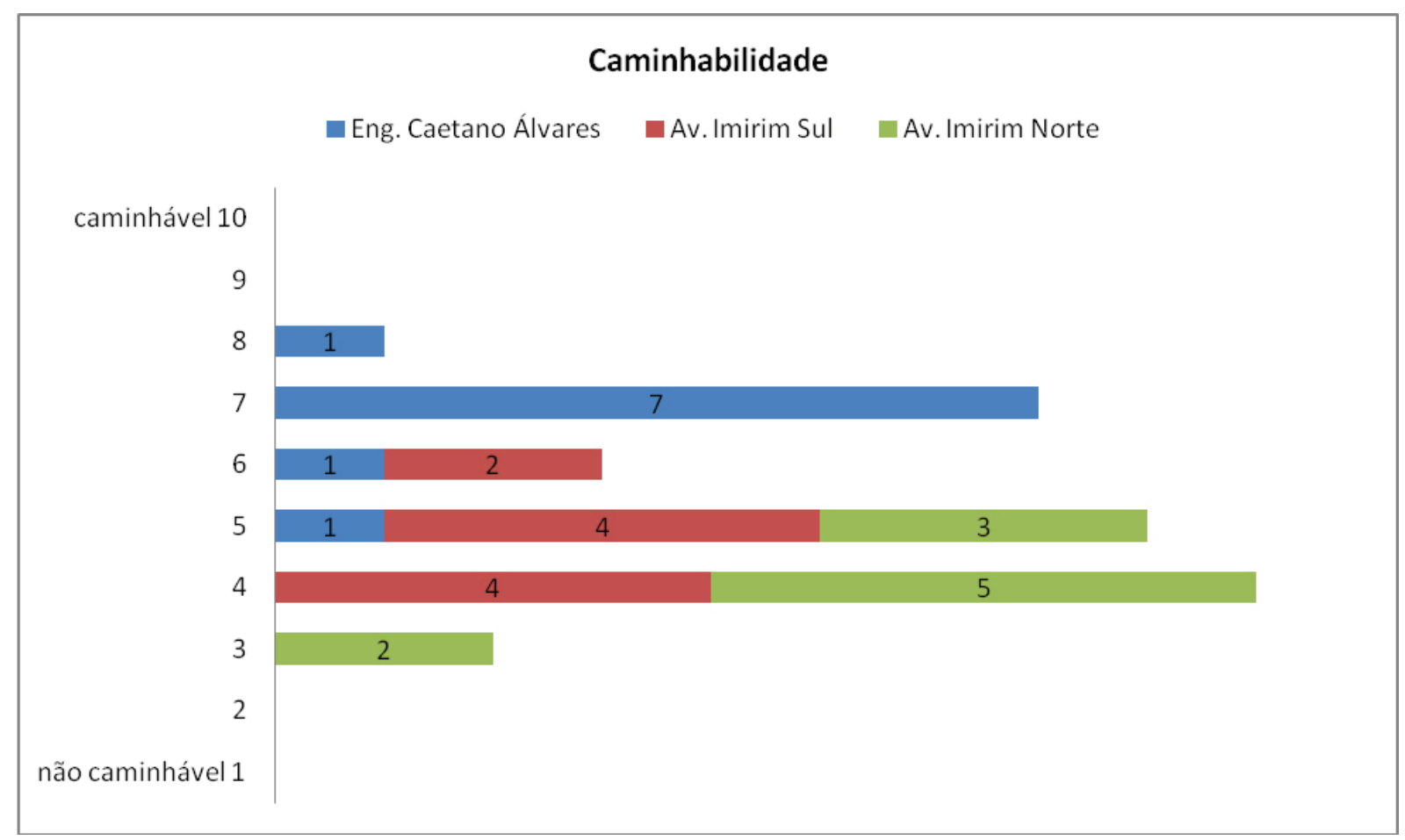

Gráfico 08 - Comparativo Caminhabilidade

Quanto às percepções acerca da caminhabilidade das vias (Gráfico 08), a avenida Caetano Álvares, mesmo tendo o barulho e o cheiro provenientes do movimento de veículos apontados como desconfortos da caminhada, recebeu as melhores notas quanto à caminhabilidade, com média 7 . Já na avenida Imirim, embora alguns parâmetros sejam piores percebidos no trecho sul, a percepção de caminhabilidade foi ligeiramente melhor nessa áraea onde, 2 dos entrevistados aferiram nota 6 e 4 entrevistados nota 5, enquanto no trecho norte a maioria dos entrevistados elegeu a nota 4. As notas aferidas pelos pedestres seguindo suas percepções de caminhabilidade coincidem com os resultados encontrados pelas análises feitas com os parâmetros da qualidade física do PEQI.

\section{CONSIDERAÇÕES FINAIS}

A área de estudo, apesar de acomodar usos do solo distintos ainda concentra aqueles comerciais e residenciais, havendo pouca mistura entre eles, o que acarreta numa monotonia urbana e utilização do espaço público em períodos restritos do dia. Essa restrição gera sentimento de insegurança no pedestre principalmente nos horários de menor movimento (GEHL, 2015; FARR, 2008; JACOBS, 2000). Além disso, a existên- 
cia de comércios dedicados ao automóvel reforça a utilização desse meio de transporte em detrimento à caminhada e não favorece a criação de um ambiente que convide o pedestre a circulação.

O fluxo de pedestres pelas vias tem várias motivações, como estudo, trabalho, serviços e o acesso a meios de transporte público, mas o ato de caminhar só foi visto ocorrendo de forma espontânea ao longo do canteiro central da avenida Engenheiro Caetano Álvares, o único local com uma fileira contínua de árvores, que garante meIhor conforto ambiental, pavimento praticamente plano e no geral, em bom estado de conservação além de possuir equipamentos para exercícios dispostos no trajeto. Essa área, embora esteja localizada entre as pistas da avenida, tem largura mais confortável e segura do que muitas das calçadas analisadas, proporcionando uma sensação de segurança em relação aos veículos, maior nesse trecho.

Apesar da proximidade à serra da Cantareira a área de estudo se mostrou muito árida, com pouca vegetação disposta ao longo das vias. A excessão é o canteiro central da avenida Engenheiro Caetano Álvares, arborizada em toda a extensão onde o córrego Mandaqui é tamponado. Esse paradoxo gera conflito quanto à questão de reabertura do córrego para sua devolução à paisagem. Uma alternativa que considerasse a requalificação da largura completa do eixo poderia favorecer a incursão de estratégias de drenagem que mimetizassem os processos naturais, como aquelas propostas pela Infraestrutura Verde (BENEDICT, M. A. e MCMAHON, E. T, 2006), requalificando ao mesmo tempo o corpo d'água, as áreas verdes e as áreas destinadas à mobilidade, através de uma paisagem com caráter multifuncional. Além disso, esses dispositivos verdes, aliados a estratégias de coleta e destinação efetiva de resíduos sólidos, poderia garantir que processos de biorretenção ocorressem durante os eventos de chuva, minimizando a carga poluidora difusa despejada nos corpos d'água, atual problema de contaminação da bacia do Mandaqui.

A partir do eixo da avenida Engenheiro Caetano Álvares, pensado como objeto catalizador do desenvolvimento urbano e ambiental na região norte de São Paulo, será possível a ramificação de uma rede integrada de ruas pensadas a partir do pedestre (GEHL, 2015; FARR, 2008; JACOBS, 2000) e que sigam pelas principais vias transversais coletoras, como a Avenida Imirim e posteriormente alcance as vias secundárias e locais, interiores aos bairros, permeando as áreas verdes e azuis no tecido urbano. Tais estratégicas podem ser capazes de reduzir ou mitigar o fenômeno de llha de calor Urbano identificado nessa área, enquanto requalificam o espaço pedonal. Por fim, o sonho de cidades vivas, seguras, sustentáveis e saudáveis como apontado por 
Gehl (2015), esbarra em desafios sociais importantes e recorrentes nas cidades brasileiras. A provisão de moradia digna, somada ao conjunto de infraestruturas que garantam qualidade de vida para todos ainda desafia governantes e planejadores. $\mathrm{Na}$ área estudada por exemplo, foi encontrado dois pequenos grupos de pessoas em condições de vulnerabilidade, ocupando as áreas verdes localizadas na av. Imirim e no entroncamento das avenidas Caetano Álvares e Direitos Humanos. Paralelamente, foi observado um certo caráter transicional no trecho da avenida Imirim direção norte e av. Eng. Caetano Álvares, onde vários comércios estão fechados e residencias foram colocadas à venda. A reocupação ou requalificação desses locais potencialmente poderão colaborar para o assentamento da população vulnerável, melhoramento e ampliação de áreas verdes e para um desenho urbano mais amigável onde as pessoas sintam-se à vontade para usufruir o espaço público como extensões de suas casas, de forma segura e confortável. Cidades caminháveis pressupõem cidades mais justas e acessíveis não apenas fisicamente, mas socialmente.

\section{REFERÊNCIAS}

BENEDICT, Mark A., MCMAHON, Eduward T. Green infrastructure: Linking landscapes and communites. Washington, DC: ISLAND PRESS, 2006.

FARR, Douglas. Sustainable Urbanism: Urban Design with Nature. Part III: Emerging Thresholds of Sustainable Urbanism (p. 102 -204). USA. 2008

GEHL, Jan. Cidades Para Pessoas; tradução Anita Di Marco. 3.ed. São Paulo: Perspectiva, 2015.

JACOBS, Jane. Morte e vida das grandes cidades. São Paulo: Martins Fontes, 2000.

RIBEIRO, Maria E. J. Infraestrutura verde, uma estratégia de conexão entre pessoas e lugares: por um planejamento ecológico para Goiânia. Tese (Doutorado) Goiânia; Universidade de São Paulo, Faculdade de Arquitetura e Urbanismo, 2010.

SVMA, 2011. Porcentagem de área verde em relação á área total da subprefeitura. (Departamentos de Planejamento Ambiental e Parques e Áreas Verdes), da Secretaria Estadual do Meio Ambiente e Secretaria Municipal de Desenvolvimento Urbano (projeção da população, a partir do CENSO/IBGE). - Elaboração: SVMA (Secretaria Municipal de Verde e Meio Ambiente). 


\section{Sites conslutados}

GEOSAMPA <www.geosampa.sp> acesso em 10/05/2016

ATLAS AMBIENTAL <www.atlasambiental.prefeitura.sp.gov.br>acesso em 10/05/2016 UCLA <http://stpp.ucla.edu/node/530> acesso em 25/04/2016

FOLHA DE SÃO PAULO <http://www1.folha.uol.com.br/cotidiano/2015/07/1660550corrego-na-zona-norte-de-sp-passa-a-ter-agua-limpa-mas-peixes-nao-voltam.shtml > acesso em 26/04/2016 